\title{
Morphological Studies of Normal Human Placenta At Different Gestational Periods
}

\author{
C.K.Lakshmi devi ${ }^{1}$, Shashank Neelam ${ }^{2}$, N.S.Raghupathy3 \\ ${ }^{I}$ Associate professor, Dept of Anatomy, S.V.Medical College,Tirupati,India. \\ ${ }^{2}$ Junior resident,AIMS Medical College,B.G.Nagara,Karnataka,India. \\ ${ }^{3}$ Professor, Dept of paediatrics ,P.Siddartha.Medical college, Vijayawada,A.P.India.
}

\begin{abstract}
The placental complex formed by the cooperative effort between the extra embryonic tissue of the embryo and the endometrial tissue of the mother represents symbiosis between the two separate organisms without rejection. The formation of placenta is a biological event which is important both embryologically and immunologically. The growth of the foetus depends upon the functional capacity, location and integrity of the placental attachment. The placenta serves the most basic metabolic needs of fetus including respiration, nourishment and excretion by acting as a temporary lung, liver and kidney. It forms an organ for the interchange of material between fetal and maternal blood streams without mixing or physical contact of two blood streams. Here I am presenting morphological findings of 50 placenta at different gestational ages. present study was conducted in the Department of anatomy Sri venkateswara medical college, Tirupati in collaboration with the department of Obstetrics and Gynecology of maternity hospital Tirupati. It was observed that Out of 50 placentae central attachment is observed in 58\% of cases, eccentric attachment in 20\%, marginal attachments in $20 \%$ and velamentous attachment in $2 \%$ of cases. The following data was recorded the study. Consistency,Cord attachment, Thickness of placenta, Weight, diameter, of the placenta observed The Feto placental weight ratio observed in 50 cases ranged between 3.75-7.7. Number of maternal cotyledons observed ranged between 12 to 20 and foetal cotyledons 36 to 84. The ratio of maternal and foetal cotyledons ranged between 2.22 - 4.6 The placental vascular pattern is disperse in type in all cases. In all 50 cases the umbilical cord contains two arteries and 1 vein.
\end{abstract}

Keywords: placental complex,velamentous attachment,cotylydons,fetoplacentral ratio,vascular pattern

\section{Introduction}

The biochemical and physical duet of the mother and the fetus in the formation of the placenta is one of the most carefully orchestrated phenomenons in the fetal development. It represents the cooperation of two distinct individuals to form a single structure that protects one and enables the genes of the other to live on. This Marvel is a miracle but an example of evolution at its finest. The important tasks like hormone synthesis, protein synthesis, immunological role and production of endocrine secretions are carried out by the placenta. The placenta is analogous to organs like liver, lung and kidney in function but not homologous with them in structure It forms the morphological record of anatomical condition, intrauterine events and intrapartum events of gestation.here It forms an organ for the interchange of material between fetal and maternal blood streams without mixing or physical contact of two blood streams. Placenta sub serves these purposes until sufficient maturation of the fetus which enables it to survive in the extrauterine environment. The growth of the foetus depends upon the functional capacity, location and integrity of the placental attachment.

\section{Materials And Methods}

The present study was conducted in the department of Anatomy,Sri Venkateswara Medical College, Tirupati in collaboration with the Department of Obstetrics and Gynecology of Maternity hospital ,Tirupati.A total number of 50 normal full term placentae with $5 \mathrm{cms}$ length of umbilical cord were collected from the Govt. Maternity hospital and relevant medical history of the mother were noted from the data available in the Hospital records. The specimens were brought to the Department of Anatomy S.V.Medical College and washed under running tap water to remove the blood clots and blotted with absorbable cloth to make them dry. The following data was recorded. Shape,Consistency,Cord attachment, Thickness of placenta is measured by inserting the fine needle through and through and measured upto nearest millimeters, Weight measured up to nearest grams with weighing machine, Diameter of the placenta is measured by taking as average of the diameter in three variousplangs with measuring tape,By dissection method the number of fetal cotyledons-are counted. Feto placental weight ratios are recorded. 


\section{Observations}

Various observations on gross appearance of human placentae were recorded in specially designed data sheets and analysed. The study is done in 50 placentae for each of the above method. The observation made during the course of the present study with relevance to the shape of placentae, consistency, cord attachment, thickness and diameter, weight, fetoplacental weight ratio are tabulated in the foregoing pages Table 1 \&Figure 1 showed the observations of cord attachment.The thickness of all the 50 placentae varied from 1.8 to $3.5 \mathrm{cms}$ as shown in the table. 2 the diameter of placentae showed in Table 3 ranged $14.2-17.5 \mathrm{cms}$. The maximum diameter of $17.5 \mathrm{cms}$ is recorded in $2 \%$ of cases . Table 4 showed weight of placentae Out of 50 cases the weight of the placenta observed ranged between 321 to 534 gms. The Feto placental weight ratio observed in Table 5 ranged between 3.75-7.7. Maternal cotyledons observed ranged between 12 to 20 and foetal cotyledons 36 to 84 . The ratio of maternal and foetal cotyledons ranged between 2.22 - 4.6.in Table6 The highest incidence of 1:3.5 is observed in 14\% of cases. Vascular pattern is disperse type in all placentae.vessels in umbilical cord are two arteries and one vein only.

Table: 1 Cord attachment

\begin{tabular}{|l|c|c|}
\hline Types of attachment & No. of placentae & Percentage \\
\hline Central attachment & 29 & $58 \%$ \\
\hline Eccentric insertion & 10 & $20 \%$ \\
\hline Marginal insertion & 10 & $20 \%$ \\
\hline Velamentous insertion & 1 & $2 \%$ \\
\hline
\end{tabular}

Fig:1 CORD ATTACHMENT

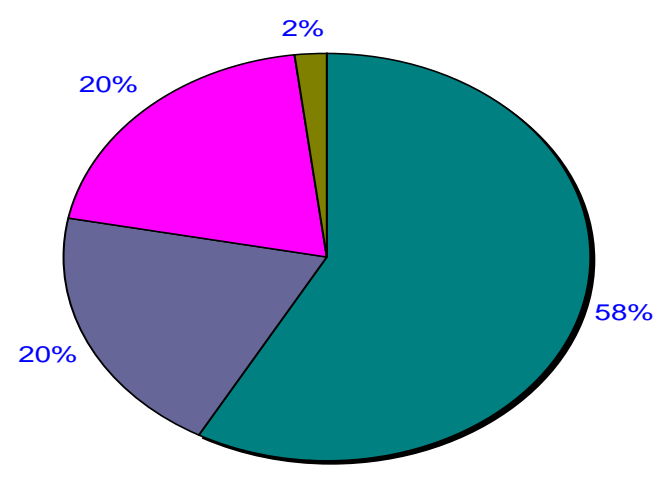

Central attachment

$\square$ Eccentric insertion

$\square$ Marginal insertion

$\square$ Velamentous insertion

TABLE-2

THICKNESS OF THE PLACENTAE

\begin{tabular}{|c|c|c|}
\hline $\begin{array}{c}\text { Thickness in } \\
(\mathbf{c m s})\end{array}$ & No. of Placenta & Percentage \\
\hline 1.8 & 3 & $6 \%$ \\
\hline 2.1 & 1 & $2 \%$ \\
\hline 2.2 & 1 & $2 \%$ \\
\hline 2.3 & 4 & $8 \%$ \\
\hline 2.4 & 6 & $12 \%$ \\
\hline 2.5 & 16 & $32 \%$ \\
\hline 2.6 & 5 & $10 \%$ \\
\hline 2.8 & 7 & $14 \%$ \\
\hline 2.9 & 2 & $4 \%$ \\
\hline 3.1 & 2 & $4 \%$ \\
\hline 3.2 & 1 & $2 \%$ \\
\hline 3.4 & 1 & $2 \%$ \\
\hline 3.5 & 1 & $2 \%$ \\
\hline
\end{tabular}


TABLE-3

DIAMETER OF PLACENTAE

\begin{tabular}{|c|c|c|}
\hline $\begin{array}{c}\text { Diameter } \\
(\mathbf{c m s})\end{array}$ & $\begin{array}{c}\text { No. of } \\
\text { Placenta }\end{array}$ & Percentage \\
\hline 14.2 & 1 & $2 \%$ \\
\hline 4.5 & 5 & $10 \%$ \\
\hline 15 & 2 & $4 \%$ \\
\hline 15.1 & 1 & $2 \%$ \\
\hline 15.2 & 7 & $14 \%$ \\
\hline 15.3 & 4 & $8 \%$ \\
\hline 15.4 & 2 & $4 \%$ \\
\hline 15.5 & 1 & $2 \%$ \\
\hline 15.6 & 1 & $2 \%$ \\
\hline 15.7 & 3 & $6 \%$ \\
\hline 15.8 & 1 & $2 \%$ \\
\hline 15.9 & 2 & $4 \%$ \\
\hline
\end{tabular}

\begin{tabular}{|c|c|c|}
\hline $\begin{array}{c}\text { Diameter } \\
(\mathbf{c m})\end{array}$ & $\begin{array}{c}\text { No. of } \\
\text { Placenta }\end{array}$ & Percentage \\
\hline 16 & 2 & $4 \%$ \\
\hline 16.1 & 1 & $2 \%$ \\
\hline 16.2 & 1 & $2 \%$ \\
\hline 16.3 & 4 & $8 \%$ \\
\hline 16.4 & 4 & $8 \%$ \\
\hline 16.6 & 1 & $2 \%$ \\
\hline 16.8 & 2 & $4 \%$ \\
\hline 16.9 & 2 & $4 \%$ \\
\hline 17.1 & 1 & $2 \%$ \\
\hline 17.3 & 1 & $2 \%$ \\
\hline 17.5 & 1 & $2 \%$ \\
\hline Total & $\mathbf{5 0}$ & $\mathbf{1 0 0 \%}$ \\
\hline
\end{tabular}

Table No-4

WEIGHT OF PLACENTAE

\begin{tabular}{|c|c|c|}
\hline $\begin{array}{c}\text { Weight in } \\
\text { grams }\end{array}$ & $\begin{array}{c}\text { No. of } \\
\text { Placenta }\end{array}$ & Percentage \\
\hline 321 & 1 & 2 \\
\hline 325 & 1 & 2 \\
\hline 375 & 2 & 4 \\
\hline 403 & 2 & 4 \\
\hline 423 & 1 & 2 \\
\hline 424 & 1 & 2 \\
\hline 425 & 1 & 2 \\
\hline 432 & 1 & 2 \\
\hline 434 & 1 & 2 \\
\hline 450 & 1 & 2 \\
\hline 451 & 1 & 2 \\
\hline 452 & 3 & 6 \\
\hline 453 & 4 & 8 \\
\hline 456 & 1 & 2 \\
\hline 458 & 2 & 4 \\
\hline 462 & 1 & 2 \\
\hline 463 & 1 & 2 \\
\hline 467 & 1 & 2 \\
\hline 470 & 1 & 2 \\
\hline
\end{tabular}

\begin{tabular}{|c|c|c|}
\hline $\begin{array}{l}\text { Weight in } \\
\text { grams }\end{array}$ & $\begin{array}{c}\text { No. of } \\
\text { Placenta }\end{array}$ & Percentage \\
\hline 475 & 2 & 4 \\
\hline 476 & 1 & 2 \\
\hline 478 & 1 & 2 \\
\hline 482 & 1 & 2 \\
\hline 483 & 1 & 2 \\
\hline 488 & 1 & 2 \\
\hline 489 & 2 & 4 \\
\hline 490 & 1 & 2 \\
\hline 495 & 1 & 2 \\
\hline 500 & 1 & 2 \\
\hline 501 & 1 & 2 \\
\hline 502 & 2 & 4 \\
\hline 503 & 1 & 2 \\
\hline 504 & 1 & 2 \\
\hline 505 & 1 & 2 \\
\hline 511 & 1 & 2 \\
\hline 512 & 1 & 2 \\
\hline 524 & 2 & 4 \\
\hline 534 & 1 & 2 \\
\hline
\end{tabular}

TABLE - 5

FETO PLACENTAL WEIGHT RATIO

\begin{tabular}{|r|r|r|}
\hline $\begin{array}{c}\text { Weight of } \\
\text { the Foetus } \\
\text { Gms }\end{array}$ & \multicolumn{1}{|c|}{$\begin{array}{c}\text { Weight of } \\
\text { placenta } \\
\text { Gms }\end{array}$} & F:P Ratio \\
\hline 3000 & 482 & 6.22 \\
\hline 2600 & 423 & 6.14 \\
\hline 3250 & 495 & 6.56 \\
\hline 2400 & 425 & 5.64 \\
\hline 2500 & 502 & 5 \\
\hline 2750 & 475 & 5.7 \\
\hline 3500 & 453 & 7.7 \\
\hline 3300 & 458 & 7.3 \\
\hline 3000 & 488 & 5.4 \\
\hline 3300 & 478 & 6 \\
\hline 3000 & 500 & 6 \\
\hline
\end{tabular}

\begin{tabular}{|r|r|r|}
\hline $\begin{array}{c}\text { Weight of } \\
\text { the Foetus } \\
\text { Gms }\end{array}$ & $\begin{array}{c}\text { Weight of } \\
\text { placenta } \\
\text { Gms }\end{array}$ & F:P Ratio \\
\hline 3000 & 503 & 7.72 \\
\hline 3200 & 504 & 7.2 \\
\hline 3000 & 452 & 6.6 \\
\hline 2750 & 462 & 6.1 \\
\hline 2900 & 501 & 5.8 \\
\hline 2500 & 489 & 5 \\
\hline 3250 & 463 & 6.5 \\
\hline 2700 & 489 & 7 \\
\hline 3500 & 501 & 6.7 \\
\hline 2500 & 502 & 5 \\
\hline 2200 & 450 & 6.08 \\
\hline
\end{tabular}


Morphological Studies Of Normal Human Placenta At Different Gestational Periods

\begin{tabular}{|r|r|r|}
\hline 3000 & 422 & 7.1 \\
\hline 3000 & 432 & 7.5 \\
\hline 2200 & 321 & 6.14 \\
\hline 3800 & 534 & 7.6 \\
\hline 2500 & 453 & 6.85 \\
\hline 2700 & 458 & 6.0 \\
\hline 3000 & 451 & 6.6 \\
\hline 3200 & 523 & 5.5 \\
\hline 2700 & 424 & 6 \\
\hline 3400 & 434 & 6.1 \\
\hline 3250 & 476 & 6.8 \\
\hline 2700 & 467 & 6.4 \\
\hline 2750 & 490 & 6.4 \\
\hline 2500 & 483 & 5.0 \\
\hline
\end{tabular}

\begin{tabular}{|r|r|r|}
\hline 2400 & 403 & 6 \\
\hline 3200 & 452 & 6.4 \\
\hline 3500 & 523 & 6 \\
\hline 2500 & 505 & 5 \\
\hline 2500 & 375 & 6.6 \\
\hline 2700 & 453 & 6.0 \\
\hline 2700 & 511 & 5.4 \\
\hline 2400 & 452 & 5.3 \\
\hline 2600 & 375 & 6.9 \\
\hline 3400 & 470 & 7.1 \\
\hline 2700 & 456 & 6.01 \\
\hline 3000 & 475 & 5.6 \\
\hline 3000 & 453 & 6.6 \\
\hline 3300 & 512 & 6.0 \\
\hline
\end{tabular}

TABLE - 6

PLACENTAL COTYLEDONS

\begin{tabular}{|c|c|c|}
\hline $\begin{array}{c}\text { No. of } \\
\text { maternal } \\
\text { cotyledons }\end{array}$ & $\begin{array}{c}\text { No. of foetal } \\
\text { cotyledons }\end{array}$ & $\begin{array}{c}\text { M:F } \\
\text { Ratio }\end{array}$ \\
\hline 19 & 62 & 3.2 \\
\hline 18 & 56 & 3.1 \\
\hline 18 & 40 & 2.2 \\
\hline 18 & 68 & 3.7 \\
\hline 18 & 64 & 3.5 \\
\hline 18 & 62 & 3.4 \\
\hline 16 & 56 & 3.5 \\
\hline 17 & 54 & 3.1 \\
\hline 18 & 68 & 3.7 \\
\hline 17 & 51 & 3 \\
\hline 20 & 64 & 3.2 \\
\hline 20 & 71 & 3.5 \\
\hline 15 & 42 & 2.8 \\
\hline 15 & 52 & 3.5 \\
\hline 18 & 62 & 3.4 \\
\hline 18 & 62 & 3.4 \\
\hline 15 & 48 & 3.2 \\
\hline 16 & 61 & 3.8 \\
\hline 15 & 58 & 3.8 \\
\hline 18 & 54 & 3 \\
\hline 18 & 56 & 3.1 \\
\hline 15 & 60 & 4 \\
\hline 16 & 51 & 3.1 \\
\hline 18 & 58 & 3.2 \\
\hline 18 & 72 & 3.8 \\
\hline & & \\
\hline
\end{tabular}

\begin{tabular}{|c|c|c|}
\hline $\begin{array}{c}\text { No. of maternal } \\
\text { cotyledons }\end{array}$ & $\begin{array}{c}\text { No. of foetal } \\
\text { cotyledons }\end{array}$ & $\begin{array}{c}\text { M:F } \\
\text { Ratio }\end{array}$ \\
\hline 18 & 56 & 3.1 \\
\hline 16 & 52 & 3.2 \\
\hline 12 & 48 & 4 \\
\hline 14 & 52 & 3.7 \\
\hline 18 & 80 & 4.4 \\
\hline 18 & 55 & 3 \\
\hline 18 & 71 & 3.8 \\
\hline 18 & 84 & 4.6 \\
\hline 16 & 50 & 3.1 \\
\hline 14 & 52 & 3.7 \\
\hline 14 & 36 & 2.5 \\
\hline 19 & 45 & 4.2 \\
\hline 17 & 62 & 2.6 \\
\hline 15 & 42 & 4.1 \\
\hline 14 & 36 & 3 \\
\hline 14 & 51 & 2.7 \\
\hline 14 & 64 & 3.5 \\
\hline 15 & 39 & 4.2 \\
\hline 16 & 64 & 2.4 \\
\hline 17 & 62 & 3.5 \\
\hline 15 & 45 & 4.1 \\
\hline 15 & 68 & 3 \\
\hline 20 & 56 & 3.4 \\
\hline 18 & 82 & 3.1 \\
\hline 18 & 78 & 4.5 \\
\hline & & \\
\hline
\end{tabular}

III. Discussion

The present study has been taken up to know the normal and the associated variations of placentae. The present study is made in the respect of shape and consistency, attachment of the cord, diameter and thickness, placental weight, fetoplacental weight ratios, vessels in the umbilical cord, the pattern of the maternal and fetal cotyledons, vascular pattern Regarding the shape and consistency of the placenta all are discoid in shape and they are soft and friable in consistency. According to Fox. $\mathrm{H}^{16} 1978$ abnormal shapes of the placenta are placenta lobata in which the division is incomplete. According to Moore Persaud ${ }^{20} 1996$ the shape of persistent area of chorionic villi determines the shape of the placenta and usually it is a circular area giving discoid shape to the placenta. According to Benirschke \& Kaufmann ${ }^{7} 1995$ in the case of placenta succenturiata one or more lobes are present with the incidence 5\%. According to them fenestrated placenta is a rare anomaly, extrachorial placenta incidence is $5.3 \%$ in 13,500 and the incidence of ring shaped placenta is one in 6000 In the present 
study the normal and the associated anomalies with relevance to the attachment of the umbilical cord are central, eccentric, marginal and velamentous. Out of 50 placentae 29 are central, 10 are eccentric, 10 are marginal and one is velamentous insertion (Table-1). Wynn ${ }^{27} 1974$ have studied 940 placentae and found no correlation between the birth weight and site of cord insertion in normal term infants. According to Heifitz S.A ${ }^{18}$., 1996 the incidence of central attachment in $90 \%$ of cases, Marginal $8.7 \%$ of cases and $1.2 \%$ of velamentous type. According to Benirschke \& Kaufmann ${ }^{7} 1995$ reported $7 \%$ incidence of marginal insertion of the cord and also revealed that the incidence of velamentous insertion as $1.1 \%$ in the review of $1,95,000$ cases of singleton deliveries. According to them the incidence of velamentous insertion of the cord is more frequent with twins and almost the rule with triplets. In the present study the average placental thickness is around $25 \mathrm{~mm}$ (Table-2). In $32 \%$ cases thickness of the placentae is $2.5 \mathrm{~cm}$ and in $14 \%$ of cases $2.8 \mathrm{~cm}, 8 \%$ of cases $2.3 \mathrm{~cm}$ and $1.8 \mathrm{~cm}$ of $6 \%$ of cases. In the present the average diameter ranged between 14.2 to $17.5 \mathrm{cms}$ in seven cases (14\%) the diameter observed is $15.2 \mathrm{~cm}$ and the maximum diameter of $17.5 \mathrm{~cm}$ is observed in $2 \%$ of cases (Table-3). According to the Boyd \& Wynn ${ }^{27} 1974$ and Aplin ${ }^{1} 1989$ the diameter ranged from $60 \mathrm{~mm}$ at 3rd month to $180 \mathrm{~mm}$ at full term and they also stated that there is an accompanying increase in the placental weight. Benirschke \& Kaufmann ${ }^{7} 1995$ stated that the placenta increase in surface area and thickness with accompanying size and length. The diameter and thickness of placenta narrated by various authors in review of literature. According to Wilfred $\mathrm{M}$ et.a ${ }^{26}$. (1975) the placenta reaches nearly its maximum diameter during the $1^{\text {st }}$ half of the pregnancy and continues to increase in thickness throughout most of the gestational period as a result of the growth of the villi. The placental weight according to various authors

TABLE-9

\begin{tabular}{|l|r|r|}
\hline \multicolumn{1}{|c|}{ Name of the author } & \multicolumn{1}{|c|}{ Year } & \multicolumn{1}{c|}{$\begin{array}{c}\text { Placental weight ( } \\
\text { gms) }\end{array}$} \\
\hline Benirschke $^{8}$ & 1962 & $425-550$ \\
\hline Williams et al $^{28}$ & 1969 & 500 \\
\hline Boyd JD $^{11}$ & 1970 & $450-600$ \\
\hline Hamilton \& Boyd $^{12}$ & 1970 & 508 \\
\hline Fox H $^{16}$ & 1978 & 323.550 \\
\hline Asha V Kher et al $^{3}$ & 1981 & 425 \\
\hline Bhatnagar et.al $^{5}$ & 1983 & 500 \\
\hline Kaplan CG $^{19}$ & 1996 & $350-750$ \\
\hline Tewari et.al & \\
\hline In present study & 1997 & $310-510$ \\
\hline
\end{tabular}

The present study coincides with the studies of Fox H et.al ${ }^{16} .1978$, Kalpana C G et.al ${ }^{19} .1996$ and Tewari et.al ${ }^{24} .1997$. The other studies showed wide variations. Thomson et. $\mathrm{Al}^{25} .1969$ stated that if membranes and cord are attached and adherent blood clot is not removed, the weight may be increased by nearly $50 \%$ and hence wide variation have been observed (Table-9).Placental and Fetal Weight Ratio The range of the placental and fetal weight ratio ranged from 1:5-1:7.7(Table-5). According to Molteni R. A ${ }^{23}$., 1979 and Bonds et al ${ }^{29}$ 1984 the incidence of perinatal problems increased in those infants whose placental and fetal weight ratio was greater than 1:11. Benirschke \& Kaufmann $\mathrm{P}^{7} 1990$ the placental and fetal weight ratio was 1:5.9 -1:7.23. According to A.K.Datta ${ }^{4}$ (2000) in full term the ratio will be 1:7.In the present study the number of maternal cotyledons ranged from 12-20. Fetal Cotyledons are 36-84. The ratio is 1:3.45 (Table-6). According to Crowford ${ }^{15} 1959$ the total number of cotyledons remains the same throughout gestation. According to various authors the maternal cotyledon number is variable. According to, Arey $^{2}$ (1956), Williams et.al ${ }^{28}$. (1969) Bhatnagar et.al ${ }^{5} .1983$ the number is $15-20$ and according to Boyd and Hamilton ${ }^{12} 1970$ the number is $10-38$. According to Grays Anatomy ${ }^{17}$ (2005), the number of maternal cotyledons is $15-30$. In the present study all the 50 placentae exhibited disperse type of vascular pattern. Bascich \& Smout 1938 stated that the human placenta shows two types of vascular patterns. Disperse type and Magistral type. In the disperse type the calibre of umbilical artery diminishes and in magistral type this artery gives of small side arteries and almost reach the placental margin with reduction in their size. According to A.K.Datta ${ }^{4}$ (2000), in disperse type the umbilical artery divide in dichotomous manner and undergo successive reduction in calibre. In magistral type the artery maintain always the uniform calibre up to the periphery of the placenta and give off number of small side branches. In the present study in the stump of umbilical cord there are two umbilical arteries and one umbilical vein in all the 50 placentae. Bernischke \& Brown ${ }^{30} 1955$ stated that absence of one artery is associated with congenital anomalies of the fetus. Hamilton-Boyd, Mossman ${ }^{31} 1966$ stated that only one artery in present in $1 \%$ of Umbilical cords. According to Benirschke \& Driscoll ${ }^{6}$ 1967, the percentage corresponds very closely with that recorded in the literature. Fox. $\mathrm{H}^{16} 1978$ observed that careful examination may disclose a venous remnant in $5 \%$ of cases. Blank \& Byrne ${ }^{13} 1985$ identified a single umbilical artery in $1.5 \%$ cases. According to 
Catanzarite ${ }^{14} 1995$, an isolated single umbilical artery may be associated with adverse out come of pregnancy. They also have observed 46 infants with single umbilical artery and recorded 2 fetuses having lethal chromosomal abnormalities and occurrence of tracheo oesophageal fistulas

\section{IV. .Summary And Conclusion}

In the current study 50 full term normal single term placentae were collected from Govt. Maternity Hospital, Tirupati and subjected for gross inspection and dissection with relevance to shape and consistency, cord insertion, thickness, diameter, weight, feto placental weight ratio, vascular pattern in the umbilical cord and foetal and maternal cotyledons. With relevance to the shape and consistency all the 50 placentae exhibited discoid shape and are friable by consistency. Regarding insertion of the cord it is observed that $29(58 \%)$ are of central attachment,10 (20\%) marginal, $10(20 \%)$ eccentric and $1(2 \%)$ velamentous in nature and the data differed from the previous authors in the form of lowered incidence of central insertion and increased incidence of marginal insertion. It is observed that thickness of the placenta at the centre is recorded as $2.5 \mathrm{cms}$ in 16 (32\%) cases, $2.8 \mathrm{~cm}$ in $7(14 \%)$ cases, $2.3 \mathrm{~cm}$ in $4(8 \%)$ and $1.8 \mathrm{~cm}$ in $3(6 \%)$ cases. This data concurred with the previous authors. It is observed that the diameter of the placenta in the present study ranged between $14.2-$ $17.5 \mathrm{cms}$ and is the highest incidence of $14 \%$ of cases the diameter recorded is $15.2 \mathrm{~cm}$. In the present study it is observed that the weight of the placenta ranged between 321-534gms. The weight of $453 \mathrm{gms}$ is observed in highest number $(8 \%)$ of cases and data concurs with the previous authors. The vide variations mentioned by the various authors is reflected in the present study. In the present study feto placental weight ratio it is observed that the ratio ranged between 5:1-7.7:1 and this data is in accordance with previous authors. The current study exhibits disperse type of vascular pattern in all 50 cases. The expressivity regarding the fetal and maternal cotyledons it is observed that the maternal cotyledons ranged from 12 to 20 and fetal cotyledons varied from 36 to 84 and the ratio of maternal and fetal cotyledons varied between 1:2.2-1:4.6 and the maximum incidence of ratio 1:3.5 is observed in 14\% of cases. In the chapter of number of vessels in the umbilical cord two umbilical arteries and one umbilical vein are noticed in all cases Benirschke and Brown1955 stated that absence of one artery is associated with congenital abnormalities of the fetus, the study of Benirschke, and Driscoll ${ }^{9}$, S.G. 1967 corresponds with this literature . and the limited study of 50 cases did not revealed any anomaly and the incidence of it is very low according various authors.

[1]. Aplin, J.D., Jones, C.J.P. 1989, Extracellular matrix in endo metrium and deciduas. In Genbacav A, Klopper A Beaconsfield R (eds) placenta as a model and source. Plenum press : New York : p 115-128.

[2]. Arey, L.B. 1948, Anat Rec.100.636.

[3]. Asha, V.K., Meera, P., 1981, "Study of placental pathology in toxaemias of pregnancy and its foetal importance" India J. Pathol. Microbial, 24: 245:251.

[4]. Asim Kumar Datta, 2000, Human embryology, pp. 57-66

[5]. Batnagar, S.M., Kotari, M.L., Lopa, A. MAHETA., 1983, Essential of human embryology $2^{\text {nd }}$ addition, pp 69-75.

[6]. Benirschke, and Driscoll, S.G., 1967, The Pathology of the Human placenta. Springer, Berlin..

[7]. Benirschke,K.,Kaufmann,P.1995, Pathology of the Human Placenta $2^{\text {nd }}$ ed, pp 1-79. New York, Springer - Verlag,

[8]. Benirschke, K.. 1962, A Review of pathological anatomy of human placenta Am: J. obstet. Gynaecol 84:1595.

[9]. Benirschke, and Driscoll, S.G. 1967, The Pathology of the Human Placenta. Springer Berlin.

[10]. Benirschke, K., and Brown, W.H., 1955, Vascular anomaly of umbilical cord; absence of one umbilical artery in umbilical cords of normal and abnormal fetuses. Obstet. Gynec., 6, 399-404.

[11]. Boyd. J. D. 1970, The Human Placenta. Heffer, Cambridge.

[12]. Boyd.J.D., and Hamilton, W.J., 1970, The Human placenta Heffer; Cambridge.

[13]. Byrne, J., Blank, W.A., 1985, Malformation and chromosome anamoles is spontaneously aborted fetuses with single umbilical artery Am : J. obstet. Gynaecol 151:340,

[14]. Catanzarite, V.A. 1995, The clinical significance of single umbilical artery as an isolated finding on prenatal ultrasound, obstet. Gynaecol 86: 155 .

[15]. Crawford, 1962, Vascular anatomy of the human placenta. Amer. J. Obstet. Gynec., 84, 1543-1567

[16]. Fox H editor, 1978, Pathology of the placenta London 1978,Saunders.

[17]. Gray's Anatomy text book $38^{\text {th }}$ edition and $39^{\text {th }}$ edition, $2002-2005$ pp. $166-177,1341-349$.

[18]. Heifetz, S.A., 1996, "The umbilical cord obstetrically important lesions" clinical obstet. Gynaecol 30(3) $571-87$.

[19]. Kaplan, C.G. 1991, Postpartum examination of placenta obstet. Gynaecol 39 (8) 535-48.

[20]. Keith, L. Moore, T.V.N.Persaud, 1996, The Developing Human Clinically Oriented embryology, p.p 135.

[21]. Molteni, R.A. 1984, Placental growth and placental fetal weight p/f ratios throughout gestation their relationship to patterns of fetal growth Semin Perinatal 8:94

[22]. Moore \& Persuad, 1996, The developing human clinically oriented embryology $6^{\text {th }}$ edition, pp.131-140

[23]. Molteni, R.A.. 1979 Stys, S.J., and Battaglia, F.C.J. Reprod. Med. 21:327, 1978.

[24]. Tewari, K., Tyagi, S.P., Saxena, K., Usman, F, Begum, R. 1997, ultrasonographic and histological study of placenta in abnormal pregnancy cases J. Obstetrics and Gynaecology Indian 47 (1); 119-26.

[25]. Thomson, A.M., Billewicz, W.Z; Hytten, F.E; 1969, The weight of the placenta in relation to birth weight. Journal of Obstetrics and Gynaecology of British common wealth 76, $865-872$.

[26]. Wilfred M. Copenha Ver., Richard, P. Bunge., \& Mary Bartlett Bunge., PH.D. 1975, Bailey's Text book of Hitology $16^{\text {th }}$ edition, pp.606-613.

[27]. Wynn, R.M., 1974, Ultrastructural development of human decidua. Am: J. obstet. Gynaecol 118: 652 - 670. 
[28]. William,P.L.,Wendell-smith,C.P.,Treadgold,S.1969,BasicHuman embryology, $2^{\text {nd }}$ editionlippincolt : Philadelphia.

[29]. Bonds, D.R., Gabbe, S.G., and Kumar, S, 1984, Am : J. obstet. Gynaecol 149:195

[30]. Benirschke, K., and Brown, W.H., 1955, Vascular anomaly of umbilical cord; absence of one umbilical artery in umbilical cords of normal and abnormal fetuses. Obstet. Gynec., 6, 399-404.

[31]. Hamilton, W.J., Boyd, J.D., \& Mosmann, H.W. 1966, Human embryology William and Williams; Baltimore
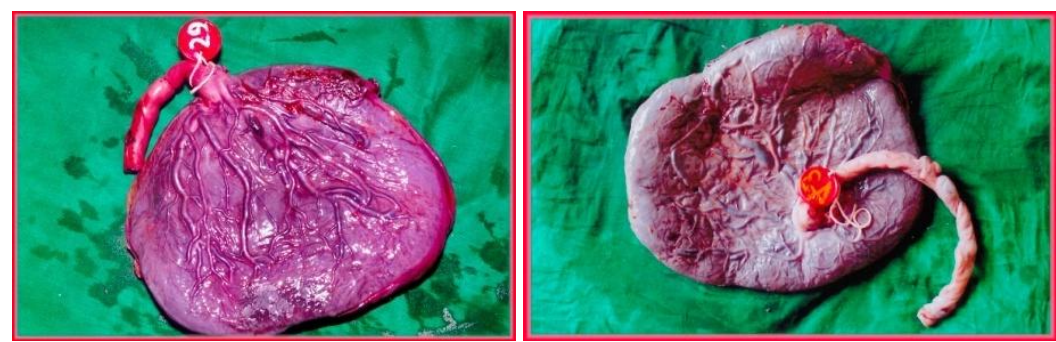

Marginal insertion of

Eccentric insertion of cord uuumbilical cord 